\title{
PENGARUH PERPUTARAN PIUTANG DAN PERPUTARAN PERSEDIAAN TERHADAP PROFITABILITAS PERUSAHAAN MANUFAKTUR YANG TERDAFTAR DI BURSA EFEK INDONESIA
}

\author{
Maristiana Ayu \\ Fakultas Ekonomi Universitas Sang Bumi Ruwa Jurai \\ maristiana.ayu@fe.saburai.ac.id
}

\begin{abstract}
Abstrak. Perputaran modal kerja dan return on asset sangat diperlukan oleh perusahaan untuk mengetahui efesien tidaknya suatu perusahaan dalam menjalankan usahanya atau kegiatannya. Mengingat bahwa modal kerja sangat dibutuhkan oleh setiap perusahaan untuk meningkatkan profitabilitas perusahaan, maka penulis tertarik untuk melakukan penelitian ini, dengan data sekunder yang digunakan adalah laporan keuangan perusahaan manufaktur food and beverages yang terdaftar di Bursa Efek Indonesia periode 2010-2014. Populasi dari penelitian ini adalah perusahaan manufaktur food and beverages yang terdaftar di Bursa Efek Indonesia (BEI) tahun 2010-2014. Metode pengambilan sampel yang digunakan adalah purposive sampling dan diperoleh 15 perusahaan sebagai sampel. Metode analisis yang digunakan adalah analisis regresi linier berganda. Permasalahan dalam penelitian ini adalah bagaimana perputaran piutang dan perputaran persediaan berpengaruh terhadap tingkat profitabilitas perusahaan, maka tujuan dari penelitian ini adalah untuk mengetahui pengaruh perputaran piutang dan perputaran persediaan terhadap tingkat profitabilitas perusahaan. Hasil penelitian ini menunjukan bahwa baik secara parsial (uji t) maupun sacara simultan (uji f), variabel perputaran piutang dan perputaran persediaan memiliki pengaruh positif signifikan terhadap tingkat profitabilitas perusahaan. Artinya semakin meningkatnya perputaran piutang dan perputaran persediaan maka akan semakin meningkatkan pula tingkat profitabilitas perusahaan.
\end{abstract}

Kata kunci: Manufaktur, Perputaran, Persediaan, Piutang, Profitabilitas.

\section{PENDAHULUAN}

Profitabilitas adalah kemampuan perusahaan memperoleh laba dalam hubunganya dengan penjualan, total aktiva maupun modal sendiri (Sartono, 2010). Bagi perusahaan masalah profitabilitas sangat penting. Bagi pimpinan perusahaan, profitabilitas digunakan sebagai tolak ukur berhasil atau tidak perusahaan yang dipimpinnya, sedangkan bagi karyawan perusahaan semakin tinggi profitabilitas yang diperoleh oleh perusahaan, maka ada peluang untuk meningkatkan gaji karyawan.

Ada beberapa rasio atau alat ukur yang dapat dipergunakan untuk mengukur tingkat profitabilitas, antara lain : return on asset (ROA) dan return on equity (ROE). $\mathrm{Di}$ dalam penelitian ini profitabilitas akan diukur dengan menggunakan return on asset (ROA).

Profitabilitas merupakan rasio untuk menilai kemampuan perusahaan dalam mencari keuntungan Profitabilitas yang tinggi akan dapat mendukung kegiatan operasional secara maksimal (Hery, 2014). Tinggi rendahnya profitabilitas dipengaruhi banyak faktor seperti modal kerja. Dalam melakukan aktivitas operasionalnya setiap perusahaan akan membutuhkan potensi sumber daya, salah satunya adalah modal, baik modal kerja seperti kas, piutang, persediaan dan modal tetap seperti aktiva tetap. Modal merupakan masalah utama yang akan menunjang kegiatan operasional 
perusahaan dalam rangka mencapai tujuannya.

Modal kerja adalah investasi perusahaan jangka pendek seperti kas, surat berharga, piutang dan inventori atau seluruh aktiva lancar (Munawir, 2012). Mengingat pentingya modal kerja didalam perusahaan, manajer keuangan harus dapat merencanakan dengan baik besarnya jumlah modal kerja yang tepat dan sesuai dengan kebutuhan perusahaan, karena jika terjadi kelebihan atau kekurangan dana hal ini akan mempengaruhi tingkat profitabilitas perusahaan. Jika perusahaan kelebihan modal kerja akan menyebabkan banyaknya dana yang menganggur, sehingga dapat memperkecil profitabilitas. Disisi lain bila kekurangan modal kerja, maka akan meghambat kegiatan operasinal perusahaan.

Berdasarkan riset yang dilakukan oleh Hastuti (2010) mengevaluasi pengaruh perputaran persediaan, perputaran hutang dagang, rasio lancar, leverage, pertumbuhan penjualan. Hasil penelitian menujukan bahwa 3 variabel yaitu periode perputaran hutang dagang, leverage dan ukuran perusahaan yang memiliki pengaruh signifikan terhadap ROA. Sedangkan variabel yang lain tidak berpengaruh signifikan terhadap ROA.

Nugroho (2011) menganalisis pengaruh likuiditas, pertumbuhan penjualan perputaran modal kerja, ukuran perusahaan dan leverage terhadap profitabilitas perusahaan (ROA), dari hasil penelitian tersebut disimpulkan bahwa hanya perputaran modal kerja, ukuran perusahaan dan leverage memiliki pengaruh yang besar terhadap tingkat profitiabilitas perusahaan sedangkan pengaruh likuiditas dan pertumbuhan penjualan tidak memilik pengaruh yang besar terhadap profitabilitas perusahaan manufaktur yang terdaftar di BEI.

Ismiati (2013) menganalisis pengaruh perputaran modal kerja terhadap profitabilitas perusahaan (ROA). Hasil penelitian menyatakan bahwa berdasarkan hasil uji analisis, perputaran modal kerja (perputaran kas, perputaran piutang dan perputaran persediaan) tidak berpengaruh terhadap profitabilitas perusahaan.

Alasan pemilihan perusahaan manufaktur khususnya perusahaan manufaktur food and beverages sebagai setting penelitian karena sektor ini merupakan industri yang masih menjanjikan keuntungan, selain itu setiap orang membutuhkan makanan dan minuman sebagai kebutuhan primer, dan sektor ini paling tahan terhadap krisis ekonomi.

Melihat kenyataan praktek dalam suatu perusahaan bahwa modal kerja sangat dibutuhkan oleh setiap perusahaan untuk membiayai kegiatan operasional sehari-hari demi untuk peningkatan profitabilitas perusahaan, maka peneliti tertarik untuk meneliti dengan judul: "Pengaruh Perputaran Piutang dan Perputaran Persediaan Terhadap Profitabilitas Perusahaan Manufaktur Food and Beverages yang Terdaftar di Bursa Efek Indonesia".

\section{KAJIAN TEORI}

\section{Pengertian Piutang}

Menurut Hery (2013) piutang dapat didefenisikan dalam arti luas sebagai hak atau klaim terhadap pihak lain atas uang, barang, dan jasa. Namun, untuk tujuan akuntansi, istilah ini umumnya diterapkan sebagai klaim yang diharapkan dapat diselesaikan melalui penerimaan kas". Dengan adanya hak klaim ini, perusahaan dapat menuntut pembayaran dalam bentuk uang atau penyerahan aktiva atau jasa lain kepada pihak siapa dia berhutang. Penjualan kredit tidak segera menghasilkan penerimaan kas, tetapi menimbulkan piutang langganan dan barulah kemudian pada hari jatuh temponya terjadi aliran 
kas masuk (cash inflows) yang berasal dari pengumpulan piutang tersebut.

Piutang (receivable) meliputi semua klaim dalam bentuk uang terhadap entitas lainnya, termasuk individu, perusahaan atau organisasi lainnya. Secara umum piutang usaha dapat didefenisikan sebagai tagihan yang timbul sebagai akibat dari penjualan barang atau jasa secara kredit. Piutang juga dapat timbul ketika suatu perusahaan memberi pinjaman uang kepada perusahaan lain dan menerima promes/wesel, melakukan suatu jasa, ataupun beberapa tipe transaksi lainnya yang menciptakan suatu hubungan antara pihak yang memberi pinjaman dengan pihak yang terhutang. Piutang dicatat dengan mendebet akun piutang usaha (account receivable) dan diklasifikasikan dalam neraca sebagai aktiva lancar.

\section{Pengertian Persediaan}

Persediaan adalah barang-barang yang biasanya dapat dijumpai di gudang tertutup, lapangan, gudang terbuka, atau tempattempat penyimpanan lain, baik berupa bahan baku, barang setengah jadi, barang jadi, barang-barang untuk keperluan operasi, atau barang -barang untuk keperluan suatu proyek (Ristono, 2013). Persediaan barang secara umum digunakan untuk menunjukkan barang - barang yang dimiliki oleh perusahaan untuk dijual kembali atau untuk memproduksi barang yang akan dijual.

(Ristono, 2013) mengemukakan bahwa : "Persediaan (atau persediaan barang dagang) secara umum ditujukan untuk barang-barang yang dimiliki perusahaan dagang, baik berupa usaha grosir maupun ritel, ketika barang -barang tersebut telah dibeli dan ada kondisi siap untuk dijual. Kata bahan baku (raw material), barang dalam proses (work in process), dan barang jadi (finished goods) untuk dijual ditujukan untuk persediaan di perusahaan manufaktur".
Persediaan dapat dibedakan menjadi persediaan perusahaan dagang dan perusahaan manufaktur. Persediaan barang dagang adalah persediaan yang dibeli dengan tujuan akan dijual kembali, sedangkan pada perusahaan manufaktur, persediaan terdiri dari persediaan bahan baku dan bahan penolong, supplies pabrik, barang dalam proses, dan produk selesai. Persediaan merupakan bagian utama dari modal kerja yang merupakan aktiva yang pada setiap saat mengalami perubahan.

\section{Profitabilitas Perusahaan}

Menurut Munawir (2012) "profitabilitas adalah menunjukkan kemampuan perusahaan untuk menghasilkan laba selama periode tertentu", dan menurut Riyanto (2011) "profitabilitas suatu perusahaan menunjukkan perbandingan antara laba dengan aktiva atau modal yang menghasilkan laba tersebut". Efisiensi perusahaan dapat diketahui dengan membandingkan laba yang diperoleh dengan modal yang menghasilkan laba tersebut atau dengan menghitung rentabilitasnya.

Menurut Ambarwati (2010), modal perusahaan pada dasarnya dapat berasal dari pemilik perusahaan yang disebut dengan modal sendiri dan modal perusahaan yang berasal dari para kreditur yang disebut dengan modal asing. Modal yang dimiliki sangat perlu dipergunakan seefektif dan seefisien mungkin. Sehubungan dengan hal tersebut, maka profitabilitas perusahaan dapat dihitung dengan dua cara :

1. Perbandingan antara laba usaha dengan seluruh modal yang digunakan (modal sendiri dan modal asing) yang disebut dengan profitabilitas ekonomi.

2. Perbandingan antara laba yang tersedia untuk pemilik perusahaan dengan jumlah modal sendiri yang dimasukkan oleh pemilik perusahaan tersebut, yang disebut profitabilitas modal sendiri atau profitabilitas usaha. 
Pengaruh Perputaran Piutang Usaha dan Perputaran Persediaan Terhadap Tingkat Profitabilitas

Piutang dan persediaan akan selalu mengalami perputaran selama perusahaan masih melaksanakan kegiatan operasionalnya. Aktiva sebagai salah satu bagian penting yang dimiliki oleh perusahaan untuk menghasilkan laba, termasuk di dalamnya adalah piutang dan persediaan. Semakin cepat atau semakin tinggi perputaran piutang dan perputaran persediaan, semakin tinggi pula tingkat profitabilitas perusahaan (Riyanto, 2011).

Hal ini disebabkan oleh semakin cepatnya perputaran piutang dan perputaran persediaan, maka modal kerja akan semakin tinggi. Modal kerja yang tinggi kemudian akan meningkatkan laba bersih perusahaan. Untuk mengetahui bagaimana tingkat perputaran piutang dan perputaran persediaaan pada perusahaan manufaktur food and beverages yang terdapat di BEI, dapat diukur pengaruhnya terhadap profitabilitas perusahaan.

\section{METODE PENELITIAN}

\section{Objek Penelitian}

Dalam penelitian ini jenis data yang digunakan adalah data kuantitatif yang berupa laporan keuangan perusahaan manufaktur food and beverages yang terdaftar di Bursa Efek Indonesia (BEI) pada tahun 2014-2016. Sumber data yang digunakan adalah data sekunder yang diperoleh secara tidak langsung atau melalui media perantara yang didapat dari website pasar modal (www.idx.co.id), kantor cabang idx Bandar Lampung, dan berbagai literatur yang ada.

\section{Populasi dan Sampel}

Populasi adalah wilayah generalisasi yang terdiri atas: obyek/subyek yang mempunyai kualitas dan karakteristik tertentu yang ditetapkan oleh peneliti untuk dipelajari dan kemudian ditarik kesimpulannya (Sugiyono, 2013). Populasi dalam penelitian ini adalah seluruh perusahaan manufaktur food and beverages yang terdaftar di Bursa Efek Indonesia (BEI) pada periode 2014-2016 yaitu sebanyak 20 perusahaan. Sampel adalah bagian dari jumlah karakteristik yang dimiliki oleh populasi (Sugiyono, 2013).

Teknik pengambilan sampel yang digunakan adalah purposive sampling jenis judgement sampling yaitu sampel dipilih dengan menggunakan pertimbangan tertentu disesuaikan dengan tujuan penelitian atau masalah penelitian yang dikembangkan.

\section{Operasional Variabel Penelitian}

Variabel terikat adalah variabel yang dipengaruhi oleh variabel bebas yang sifatnya tidak dapat berdiri sendiri serta menjadi perhatian utama peneliti. Dalam penelitian ini yang menjadi variabel terikat adalah Profitabilitas (ROA). Dalam penelitian ini yang menjadi variabel bebas adalah modal kerja yang terdiri dari perputaran piutang (sub variabel X1) dan perputaran persediaan (sub variabel X2).

\section{Metode Analisis Data}

Data yang akan dianalisis dalam penelitian ini berkaitan dengan hubungan antara variabel-variabel. Analisis data dilakukan secara kuantitatif dengan dilanjutkan pemilihan uji statistik (yaitu dengan uji reliabilitas dan validitas, uji normalitas,analisis regresi linear berganda, uji korelasi, uji t, dan uji F), tujuannya adalah menetapkan apakah variabel bebas mempunyai hubungan dengan variabel terikatnya, penetapan tingkat signifikasi dan diakhiri dengan penelitian dasar penarikan 
kesimpulan melalui penerimaan atau penolakan hipotesis.

Menurut Sugiyono (2013) menyatakan bahwa analisis data merupakan kegiatan setelah data dari seluruh responden terkumpul. Kegiatan dalam analisis data adalah megelompokkan data berdasarkan variabel dan jenis responden, menyajikan data tiap variabel yang diteliti, melakukan perhitungan untuk menjawab rumusan masalah, dan melakukan perhitungan untuk menguji hipotesis yang telah diajukan.

Adapun analisis data yang akan digunakan dalam penelitian ini adalah analisis deskriptif. Analisis deskriptif merupakan analisis yang digunakan untuk membahas data kuantitatif. Dalam analisis ini dilakukan pembahasan mengenai bagaimana pengaruh dari kondisi perputaran piutang dan perputaran persediaan terhadap profitabilitas (ROA) perusahaan.

\section{Pengujian Hipotesis}

Analisis regresi linear berganda dalam penelitian ini digunakan untuk menghitung besarnya pengaruh variabel independen (perputaran piutang dan perputaran persediaan) terhadap variabel dependen Profitabilitas (ROA).

Model regresi berganda adalah sebagai berikut :

$$
Y=\beta_{0}+\beta_{1} X_{1}+\beta_{2} X_{2}
$$

Keterangan :

Y : Profitabilitas (ROA)

$\beta_{0} \quad$ : Konstanta

$\mathrm{X}_{1} \quad$ : Perputaran piutang

$\mathrm{X}_{2} \quad$ : Perputaran persediaan

$\beta_{1-2} \quad$ : Koefisien variabel ke1 dan 2

\section{Uji Koefesiensi Determinasi (R2)}

Melihat berapa proporsi variasi dari variable bebas secara bersama-sama dalam mempengaruhi varibale tidak bebas.
Menurut (Gujarati, dalam Mei Hotma Mariati Munte, 2009) dapat dihitung dengan rumus :

$$
R^{2}=\frac{J k_{R}}{J k_{y}}
$$

Keterangan :

$$
\begin{array}{ll}
\mathrm{JK}_{\mathrm{R}} & =\text { Jumlah kuadrat regresi } \\
\mathrm{JK}_{\mathrm{Y}} & =\text { Jumlah total kaudrat }
\end{array}
$$

\section{Uji (t) Parsial}

Untuk menguji kemaknaan koefisien parsial digunakan uji t. Pengambilan keputusan dilakukan berdasarkan perbandingan nilai $\mathrm{T}_{\text {hitung }}$ masing-masing koefisien regresi dengan nilai $\mathrm{T}_{\text {tabel }}$ (nilai kritis) sesuai dengan taraf signifikansi yang digunakan. Uji t digunakan untuk menguji secara parsial antara variable bebas terhadap variable tidak bebas dengan asumsi bahwa variable lain dianggap konstan, dengan tingkat keyakinan $95 \%(\alpha=0,05)$. Uji t dapat dihitung dengan menggunakan rumus :

$$
T_{\text {hitung }}=\frac{b_{i}}{s b_{i}}
$$

\section{Keterangan :}

$b_{i} \quad$ : koefesien regresi masing-masing variable

$\mathrm{sb}_{\mathrm{i}} \quad$ : standar error masing-masing variable.

\section{Uji (F) Simultan}

Untuk membuktikan kebenaran hipotesis, peneliti menggunakan uji $\mathrm{F}$ yaitu untuk mengetahui sejauh mana variabel $\mathrm{X} 1$ dan X2 mampu menjelaskan atau berkontribusi terhadap variabel Return saham dengan cara membandingkan Fhitung dengan Ftabel. Dengan maksud menguji apakah secara simultan variable bebas 
berpengaruh terhadap variable tidak bebas, dengan tingkat keyakinan $95 \%(\alpha=0,05)$. Uji $\mathrm{F}$ dapat dihitung dengan menggunakan rumus yaitu :

$$
\mathrm{F}=\frac{\mathrm{R} 2 / \mathrm{K}}{(1 \mathrm{R} 2) / \mathrm{n}-\mathrm{k}-1}
$$

Keterangan :

R2 : Koefesien determinasi

N : Jumlah Sample

$\mathrm{K} \quad$ : Jumlah variable bebas

Dengan kriteria tersebut, diperoleh nilai Fhitung yang dibandingkan dengan Ftabel dengan tingkat resiko dalam hal ini 0,05 dan tingkat kebebasan $=\mathrm{n}-\mathrm{k}-1$.

Dimana :

$\mathrm{F}_{\text {hitung }}>\mathrm{F}_{\text {tabel }}=\mathrm{Ha}$ diterima dan $\mathrm{H} 0$ ditolak $\mathrm{F}_{\text {hitung }}<\mathrm{F}_{\text {tabel }}=\mathrm{Ha}$ ditolak dan $\mathrm{HO}$ diterima.

\section{HASIL DAN PEMBAHASAN}

\section{Pengujian Hipotesis}

Nilai Korelasi (R) sebesar 0,524 maka dapat diinterpretasikan berdasarkan tabel interpretasi bahwa hubungan variabel independen bebas (perputaran piutang dan perputaran persediaan) terhadap variabel dependen (profitabilitas) dapat di kategorikan sedang.

Nilai Koefisien Determinasi (R2) adalah sebesar 0,274 atau $27,4 \%$ yang artinya bahwa pengaruh variabel independen bebas (perputaran piutang dan perputaran persediaan) terhadap variabel dependen (profitabilitas) adalah sebesar 27,4\%, sedangkan sisanya $72,6 \%$ dipengaruhi oleh faktor- faktor lain diluar pembahasan ini.

Nilai Adjusted $R$ Square sebesar 0,250 maka dapat diinterpretasikan berdasarkan tabel interpretasi bahwa pengaruh variabel $\mathrm{X}_{1}$ (perputaran piutang dan variabel $\mathrm{X}_{2}$ (perputaran persediaan) terhadap variabel $\mathrm{Y}$ (profitabilitas) di katakan rendah.
Standard Error of The Estimate diperoleh angka senilai 3,47404 yang berarti bahwa tingkat kesalahan dalam menjelaskan variabel perputaran piutang dan variabel perputaran persediaan terhadap profitabilitas, hanya sebesar 3,47404\% $(3,47404 \times 100 \%)$.

Berdasarkan hasil olah data variabel perputaran piutang dan perputaran persediaan yang memiliki pengaruh yang bermakna secara parsial terhadap Profitabilitas dengan menggunakan statistik $-\mathrm{t}($ student $-\mathrm{t})$ pada tingkat kepercayaan $95 \%$ $(\alpha=0,05)$ diperoleh hasil sebagai berikut:

1. Pengaruh perputaran piutang terhadap profitabilita (ROA) mempunyai angka signifikasi sebesar $0.007(<\alpha=0,05)$ yang berati lebih kecil dari 0,05 , yang menunjukkan bahwa tingkat perputaran piutang berpengaruh signifikan terhadap profitabiltas perusahaan.

2. Pengaruh perputaran persediaan terhadap profitabilitas (ROA) mempunyai angka signifikasi sebesar $0,000(<\alpha=0,05)$ yang berati lebih kecil dari 0,05 , yang menunjukkan bahwa tingkat perputaran persediaan berpengaruh signifikan terhadap profitabiltas perusahaan.

\section{Pembahasan Hasil Penelitian}

Berdasarkan hasil uji $F$, dapat disimpulkan bahwa semua variabel independen yaitu perputaran piutang dan perputaran persediaan berpengaruh positif signifikan terhadap variabel dependen profitabilitas, yang ditunjukkan oleh nilai signifikansi $F(0,000)<0,05$ dan $F$ Hitung 11,343 > F tabel 3,150. Hasil ini didukung dari nilai koefisien determinasi (R2) sebesar 0,274 atau $27,4 \%$ yang berarti bahwa pengaruh variabel independen bebas (perputaran piutang dan perputaran persediaan) terhadap variabel dependen (profitabilitas) adalah sebesar 27,4\%, 
sedangkan sisanya $72,6 \%$ dipengaruhi oleh faktor-faktor lain diluar pembahasan ini.

Hasil penelitian secara simultan mendukung hasil penelitian yang dilakukan oleh Nina Sufiana (2011) dan Ni Ketut Purwati (2011) yang menyimpulkan bahwa hasil regresi berganda menunjukkan bahwa secara simultan terdapat pengaruh yang signifikan antara perputaran piutang dan perputaran persediaan terhadap profitabilitas perusahaan. Akan tetapi secara parsial, hasil penelitian tidak mendukung hasil penelitian yang dilakukan oleh Meria Fitri (2013) dan Nike Ismiati (2013) .

Dari hasil pengujian variabel penelitian secara parsial, didapati bahwa variabel independen, yaitu perputaran piutang berpengaruh positif signifikan terhadap variabel dependen yaitu ROA. Hasil ini sesuai dengan nilai signifikansi $\mathrm{t}$ untuk variabel perputaran piutang $(0,007)$ yang lebih kecil dari 0,05 . Nilai signifikansi ini didukung dengan nilai $\mathrm{t}$ hitung 2,798 > t tabel 2,000297804. Begitu juga dengan variabel perputaran persediaan yang memiliki pengaruh positif signifikan, dengan nilai signifikansi untuk perputaran persediaan $(0,000)$ yang lebih kecil dari 0,05 dan nilai $\mathrm{t}$ hitung $3,953>\mathrm{t}$ tabel 2.000297804 .

Hasil ini sangat berbeda dengan peneliti terdahulu yang mendapatkan hasil bahwa perputaran piutang dan perputrana persediaan tidak berpengaruh signifikan terhadap profitabilitas perusahaan. Hal ini mungkin dikarenakan berbedanya periode yang digunakan dalam penelitian, dan juga dikarenakan perbedaan objek penelitian, yang mana penelitian ini meneliti lebih dari satu perusahaan yaitu perusahaan food and beverages yang terdaftar di Bursa Efek Indonesia.

Secara parsial penelitian ini mendapatkan hasil bahwa perputaran persediaan berpengaruh terhadap tingkat profitabilitas perusahaan. Hasil ini tidak mendukung hasil dari peneliti terdahulu yang mengatakan bahwa tidak terdapat pengaruh antara perputaran persediaan dengan profitabilitas perusahaan. Hal ini mungkin disebabkan bedanya bentuk persediaan yang dimaksud dari peneliti terdahulu. Hal lain yang melatarbelakangi adalah kebijakan persediaan yang kurang baik. Piutang lebih cepat dikonversikan ke kas dari pada persediaan, sehingga perlu pengawasan dan perhitungan yang tepat.

\section{KESIMPULAN DAN SARAN}

\section{Kesimpulan}

Berdasarkan hasil analisis dan pembahasan pada penelitian ini, maka dapat disimpulkan bahwa perputaran piutang secara parsial berpengaruh positif signifikan terhadap profitabilitas perusahaan manufaktur food and beverages yang terdaftar di Bursa Efek Indonesia. Perputaran persediaan secara parsial berpengaruh positif signifikan terhadap profitabilitas perusahaan manufaktur food and beverages yang terdaftar di Bursa Efek Indonesia. Perputaran piutang dan perputaran persediaan secara simultan atau secara bersama-sama berpengaruh positif signifikan terhadap profitabilitas perusahaan manufaktur food and beverages yang terdaftar di Bursa Efek Indonesia, dengan signifikan 0,000 . Artinya secara bersamasama meningkatnya perputaran piutang dan perputaran persediaan akan meningkatkan tingkat profitabilitas perusahaan.

\section{Saran}

Berdasarkan hasil penelitian ini, peneliti mencoba memberikan saran sebagai berikut

1. Bagi pihak perusahaan

perlu memperhatikan pemberian pinjaman kredit bagi pelanggan ataupun pihak lain karena perputaran piutang 
yang terjadi akan sangat mempengaruhi laba bersih perusahaan.

2. Bagi investor

Dengan adanya penelitian ini maka investor disarankan agar bisa lebih selektif lagi dalam memilih perusahaan yang akan dijadikan tempat untuk investasi.

\section{DAFTAR PUSTAKA}

Ambarwati, Sri Dwi Ari. 2013. Manajemen Keuangan Lanjutan. Edisi Pertama. Yogyakarta: Graha Ilmu.

Bursa Efek Indonesia. Indonesian Capital Market Directory 2014-2016. Jakarta: PT Bursa Efek Indonesia. www.idx.co.id

Ghozali, Imam. 2013. Aplikasi Analisis Multivarite Dengan Program IBM SPSS 21 Update PLS Regresi. Semarang: Universitas Diponegoro.

Hery, 2013. Akuntansi Keuangan Menengah. Cetakan pertama. Yogyakarta: CAPS (Center of Academic Publishing Service).

Hery, 2014. Analisis Laporan Keuangan. Edisi Pertama, Cetakan Ke-2. Jakarta: Bumi Aksara.

Kasmir. 2011, "Analisis Laporan Keuangan”. Edis 1, Cetakan ke-6. Jakarta: Rajawali Pers.

Munawir, 2012. Analisa Laporan Keuangan. Yogyakarta: Liberty.

Putra, Lutfi Jaya. 2012. Pengaruh Perputaran Modal Kerja Terhadap Profitabilitas (Studi Kasus : PT. Indofood Sukses Makmur Tbk).
Jurnal Ekonomi Gunadarma, Vol.09. No.01. Pp 1-10.

Ristono, Agus. 2013. Manajemen Persediaan. Edisi Pertama. Cetakan ke-2. Yogyakarta: Graha Ilmu.

Riyanto, Bambang. 2011. Dasar Dasar Pembelanjaan Perusahaan. Edisi Keempat. Yogyakarta: BPFE.

Santoso, Singgih. 2010. Statistik Parametrik. Jakarta: PT. Elex Media koputindo.

Sartono, Agus. 2010. Manajemen Keuangan Teori dan Aplikasi. Edisi Keempat. Yogyakarta: BPFE.

Subramanyam, K.H \& Wild, Jhon J. 2011. Analisis Laporan Keuangan. Buku 2, Jakarta: Salemba Empat.

Sugiyono, 2013. Statistika untuk Penelitian. Cetakan ke-23. Bandung: Afabeta.

Sujarweni, V. Wiratna. 2015. SPSS untuk Penelitian. Yogyakarta: Pustaka Baru Perss.

Trihendradi, Cornelius. 2013. Step by Step IBM SPSS 21 Analisis Data Statistik. Edisi Pertama. Yogyakarta: ANDI.

Warren, Carl S., James M. Reeve, dan Jonathan E. Duchac. 2012. Pengantar Akuntansi-Adaptasi Indonesia. Buku 2. Jakarta: Salemba Empat.

Wibowo, Agus dan Wartini, Sri. 2012. Efisiensi Modal Kerja, Likuiditas dan Leverage terhadap Profitabilitas pada Perusahaan Manufaktur di BEI. 
http://journal.unnes.ac.id/nju/index. php/jdm.

Wolk, Harry I., Michael G. Tearney, dan James L Dodd. 2008. Accounting Theor: A Conceptual and Institusional Approach. SouthWestren: College Publishing. 